\title{
Sedimentary controls on the reservoir properties of the Paleogene fluvio- tidal sands of the Anambra Basin, southeastern Nigeria- implication for deepwater reservoir studies
}

\author{
Nwachukwu, U.E.D, Anyiam, O.A., Egbu, O.C. and Obi, I.S. \\ Department of Geology, University of Nigeria, Nsukka.
}

\begin{abstract}
Reservoir sands from selected outcrops of the Eocene Nanka Formation were subjected to detailed field and laboratory studies in order to determine their reservoir properties. From the field studies, three lithostratigraphic units were delineated, namely- (I) basal sandstone unit of tidally influenced conglomeritic fluvial channel sandstones, (II) middle sandstone unit of tidally influenced cross-bedded sandstone unit with a thin mudrock unit, and (III) upper sandstone unit dominated by tidally influenced ferruginized sandstones with estuarine heterolith interval. The architecture of these units depicts south-easterly deposition in a tidally influenced fluvial environment. Granulometric analyses also reflect an upward decline in the sediment sorting, and an increase in clay content. The permeability values, which were generated using empirical equations, range between 49-121darcies, 37- 45darcies and 13-37darcies, for the lower, middle and upper units respectively. The porosity also shows the same trends. The result of the petrographic studies shows that the reservoir heterogeneity at the microscale are mainly controlled by compaction, fracturing of the grains, chemical dissolution of unstable minerals, pressure solutions, and cementation, while at the megascale, major controls are bioturbations, clay drapes on foreset planes of cross-beds, clay dispersal within the sands and coarse grained lags at the base of channels. The reservoir sands are compartmentalized, especially by $\mathrm{cm}$-thick elongate ferruginized and lateritic bands of sand, especially at the lower and middle sandstone units. The study of outcrop models of the inland basins is important because they increase the knowledge of reservoir heterogeneities and provides the foundation on which the rest of the subsurface reservoir simulation models can be built, especially for the petroliferous Tertiary Niger Delta Basin.
\end{abstract}

Keywords: Sedimentary controls, reservoir, Nigeria

\section{INTRODUCTION}

The Paleogene sedimentary succession in the southern Nigeria consists of the MaastrichtianPaleocene Nsukka Formation ( $350 \mathrm{~m})$, Paleocene Imo Formation $(\sim 1,000 \mathrm{~m})$, Eocene Ameki Group $(\sim 1,900 \mathrm{~m})$, and Eocene-Oligocene Ogwashi-Asaba Formation $(\sim 250 \mathrm{~m})$. These Eocene rocks that outcropped in southeastern Nigeria have been classified under the Ameki Group and comprises the Ameki Formation, Nanka Sands and the Nsugbe Sandstone. The Nanka Sands underlie the study area and have been described by many authorsTattam (1944) and Simpson (1955), Reyment (1965) and Adegoke (1969), Nwajide (1979). The study area is located in the vicinity of Awkuzu and Umunya (Onitsha expressway) towns in Anambra State and this falls within the undulating lowlands that lie along the eastern flank of the Anambra River. The area marks the western boundary of outcrops of the
Paleocene - Oligocene in Southeastern Nigeria after which the rocks become overlain by the Quaternary sediments deposited by the fluvial action of the Anambra and Niger Rivers. Rocks in the area follow a NW - SE trend and good exposures could readily be found along road cuts and quarry sites. Regional correlation (Short and Stäuble, 1967; Avbovbo, 1978) shows that the Paleogene succession can be mapped southward into the petroliferous Niger Delta where the Imo Formation, Ameki Formation and Ogwashi Asaba Formation are equivalents of the hydrocarbon-generating Akata Formation, reservoir lithofacies of the Agbada Formation and the Benin Formation respectively. With the recent renewed drive for hydrocarbon exploration in the inland basins of Nigeria, the search in the Anambra-Afikpo basin complex, is switching from the seismically defined structures to the more elusive stratigraphic traps in the Paleogene succession. Some of the world's giant oilfields are found in siliciclastic (braided fluvial) 
reservoirs in many petroleum provinces (Martin, 1993; Labourdette and Jones, 2007). These siliciclastic reservoir rocks owe much of their diversity and stratigraphic heterogeneity to the many different depositional environments in which they were deposited (Magoon and Dow, 1994). Several elements of heterogeneity like clay and mud-drapes on bedding and foreset planes, ferruginized sand horizons, fingers of offshore mudstone, carbonate cemented beds, bioturbation and coarse grained lags at base of channel have been shown to be of great consequence to the effectiveness of siliciclastic reservoir horizons in this study area. The objective of this research therefore, is to evaluate the sedimentary controls on the effectiveness of reservoirs through sedimentologic and stratigraphic analyses from outcrops of the Eocene Nanka Formation. These outcropping reservoir sands form analogue from which model reservoir architecture, reservoir quality variations, and baffles to fluid flow can be estimated. The results shall serve as a proxy for sand distribution in our deepwater reservoirs and provide a useful framework for the remodelling of the Paleogene outcropping sediments in the Anambra Basin, southeastern Nigeria.

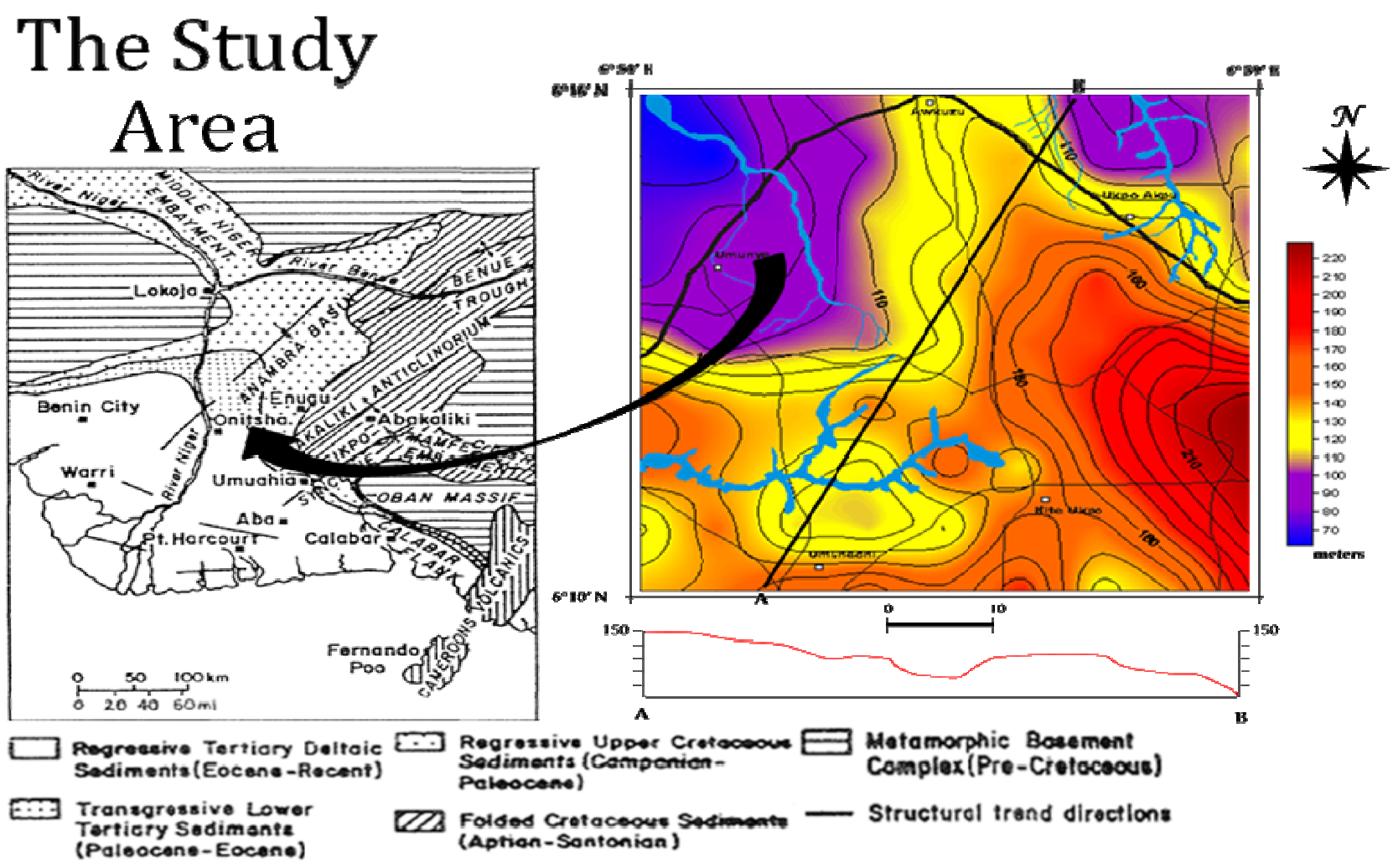

Fig 1: Geologic map of Nigeria showing the gridded portion of the study area.

\section{GEOLOGICAL SETTING}

The Anambra Basin developed as a result of the Santonian event which greatly affected the Benue Trough terminating sedimentation in the Abakaliki Basin. Before then, sedimentation in southern Nigeria which began in the Early Cretaceous was facilitated by the breakup of the African and South American continents leading to the formation of the Benue Trough (Burke et al., 1970; Benkhelil, 1989). Sedimentation in the trough was controlled by three major tectonic phases, giving rise to three successive depocentres (Murat, 1972; Oboh-lkuenobe et al, 2005).

The first phase (Albian - Santonian) featured the deposition of the Asu River Group, Eze-Aku and Awgu Formations within the Abakaliki-Benue Trough which was flanked to the east by the Anambra platform, and to the southwest by the Ikpe platform. The second phase (Campanian-Eocene) was characterized by compressive movements along the 
NE-SW axis which resulted in the folding and uplift of the Trough into an anticlinorium. This forced the Anambra platform to subside and the depocentre to shift south-westwards to the newly formed Anambra basin and the Afikpo syncline on the other side of the anticlinorium in the southeast. The deposition of the Nkporo Group, Mamu Formation, Ajali Sandstone, Nsukka Formation, Imo Formation and the Ameki Group then followed. Towards the end of Eocene, the third phase commenced and was characterized by the structural inversion of the Abakaliki region further shifting the depocentre down dip (southwards) to form the Niger Delta basin (Obi et al., 2001).

\section{DATA BASE AND METHODOLOGY}

Seven key outcrop sections in the area were mapped at road cuts and quarry sections in the UmunyaAwkuzu areas. The outcrops were studied to obtain data on the lithologic variation, sedimentary structures, reservoir and textural characteristics. Sieve data plotted on semi-log sheet were used to determine the $50^{\text {th }}$ percentile or median diameter $\left(d_{50}\right)$ and sorting. These parameters were then substituted into the empirical formula proposed by Krumbrien and Monk, 1942, to estimate permeability of the reservoir intervals. The formula is given as $K=$ $\mathrm{C}_{0} \mathrm{D}_{\mathrm{m}}^{2} \mathrm{e}^{-1.31} \sigma$ where $\mathrm{K}=$ permeability (millidarcies), $\mathrm{Co}=$ an empirical constant $\left(760\right.$ darcies $\left./ \mathrm{mm}^{2}\right), \mathrm{Dm}=$ median diameter $(\mathrm{mm})$ and $\sigma=$ sorting (in phi standard deviation). The assessment of permeability for reservoir units can be done using empirical formula since the general relationship between permeability and porosity in sandstones remains valid (Kriesa et al., 1999). Paleocurrent data were measured from the foreset planes of cross-bedded sand facies at the Umunachi, Ukpo Akpu Umunya sections using the brunton compass. Planar cross bedding recognized in this study included low-angle, high-angle and trough bed set. Sequences followed during the measurement exercise include (i) measurement of dip amounts and azimuths from cross-beds, (ii) calculation of the mean vector azimuths (MVA), variance and vector strength using Steinmetz (1962) method, MVA $=\tan ^{-1}(\Sigma \operatorname{Sin} A / \Sigma$ Cos A), Variance $(\operatorname{Var})=\Sigma\left(A_{1}-A\right)^{2} / n-1$, Vector Strenght $=$ $\sqrt{ }\left(\left(\left(\sum \operatorname{Sin} A\right)^{2}+\left(\sum \operatorname{Cos} A\right)^{2}\right) / n\right)$. Where $n$ is the number of readings, $\operatorname{Sin} A$ and $\operatorname{Cos} A$ are the sines and cosines of the individual readings, respectively, and $\Sigma \operatorname{Sin} A$ and $\Sigma$ Cos $A$ are the sums of the sines and cosines of the individual readings (Collinson and Thompson, 1989). $A_{1}$ represents the individual azimuth readings, while $A$ represent the value of the mean vector azimuth. Consolidated samples were subjected to thin-section studies using the petrographic microscope to study the microscale sedimentary controls. Moderately consolidated sediments, were impregnated with Canada balsam before the petrographic studies. Clay samples were subjected to X-ray diffraction (XRD) to determine the clay mineralogy and other silicate compositions. Matching the generated coloured peaks with already installed minerals within its software does the mineral identification. Pebble morphometry study was done to determine the depositional environments of the conglomeritic reservoir sandstones. In order to ensure accuracy and proper representation of the pebble population and dimensions, the deformed pebbles and others that appeared heterogeneous and primarily elongate were removed. Pebble morphometric study was done based on the determination of the Long (L), the intermediate (I) and the Short (S) axes of the pebbles using the veneer caliper (Sneed and Folk, 1958; Dobkins and Folk, 1970). The following interpretative indices were determined (for each pebble), Maximum Projection Sphericity (MPS, Sneed and Folk 1958), Oblate Prolate Index (OPI, Dobkin and Folk 1970) and Flatness Index (FI, Lutting, 1962) which are given as MPS $=\left(\mathrm{S}^{2} / \mathrm{LI}\right)^{1 / 3}, \mathrm{OPI}=\{[\mathrm{L}-\mathrm{I} / \mathrm{L}-\mathrm{S}]-0.5\} /\{\mathrm{S} / \mathrm{L}\}$ and $\mathrm{FI}=$ (S/L) \% respectively.

\section{RESULTS}

Based on the integration of the paleocurrent, pebble and sedimentary structure data, two major facies association, the estuarine and fluvial/tidally influenced fluvial facies, were identified in the study area. This corresponds with Nwajide's (1979) sedimentary model which depicted the Nanka Sands to be deposited in a tidally influenced marine shoreline environment with delineable intertidal zone.

\section{Facies Association I}

This is dominated by multistory sandstone with horizontal bedding, planar cross-beds and ripple lamination. Two subfacies have been identified in this association, namely conglomeritic and cross bedded subfacies (Awkuzu and Ifite Ukpo sections). This unit is about $8 \mathrm{~m}$ thick and is characterized by mud rip-up clast and conglomerates. The cross bedded facies comprises fine to coarse-grained, moderately to well sorted beds characterized by both planar crossbeds and wave ripple laminations. The beds are churned and contain burrows of Ophiomorpha and Planolites. The conglomerate facies comprises single and 
amalgamated conglomeritic sandstones. The sandstones are generally medium to coarse grained poorly sorted, locally granular and pebbly. The amalgamated sandstone units range from 0.8 - 5.0 meters in thickness showing a fining upward sequence from conglomeritic sands to fine grained

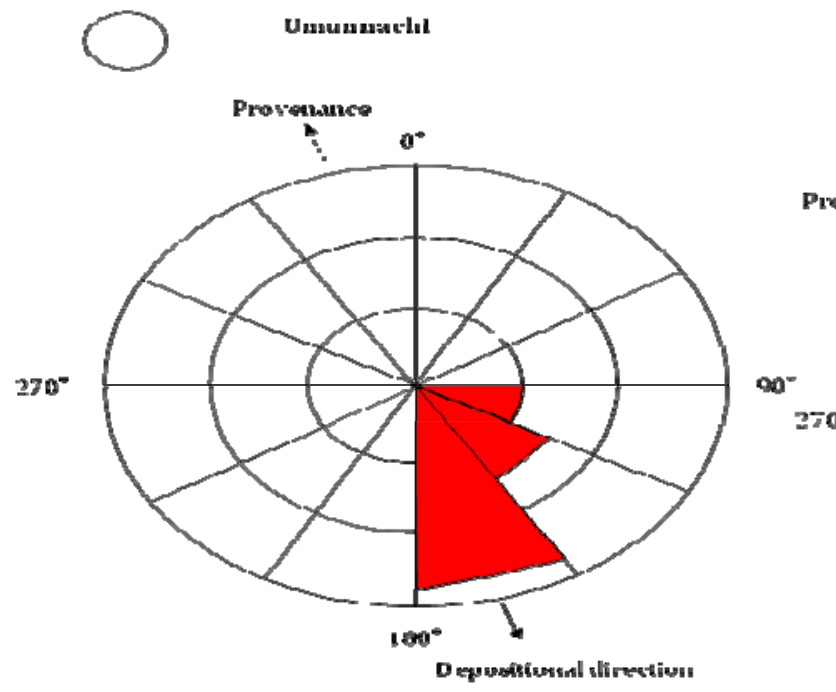

Fig 2: Rose diagrams obtained from paleocurrent data obtained from the conglomeritic and crossbedded facies (facies association I).

This facies is interpreted as fluvial and tidallyinfluenced fluvial channel deposits based on the occurrence of medium to coarse grained size sands, dominance of planar cross-beds, fining-upward trend, and evidence from paleocurrent analysis. The occurrence of thickly-bedded, channelized and matrix-supported conglomerates (which exhibit normal grading) in some sediment packages classifies them as braided channel facies (Nilsen, 1982; Miall, 1992). The channel lag deposits with scoured surfaces are mainly conglomeritic (Miall, 1978). Indicators of tidal environment are the presence of lower-bounding erosional surfaces with pebble lags, bimodal bipolar paleocurrent pattern (figure 3), dominance of bladed, very bladed and elongate pebbles (figure 4). This depositional facies is recognized based on the occurrence of coarse- matrix. Fluvial channel deposit interpretation is based on sedimentary structures and grain size trends. They are usually characterized by a fining-upward succession with unidirectional paleocurrent pattern (figures 2\&6).
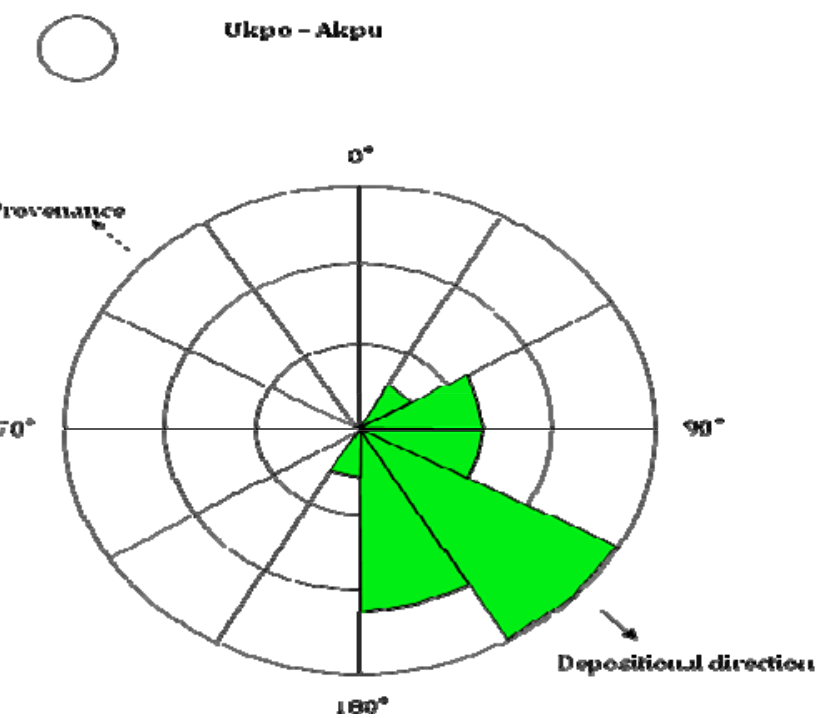

grain size, dominance of planar and trough crossbeds and tide-generated sedimentary structures namely- mud drapes, reactivation surfaces (Archer and Kvale, 1989; Leckie and Singh, 1991; Shanley et al., 1992; Hettinger, 1995). Also, the presence of Ophiomorpha and Arenicolites indicate high-energy sandy settings (Pemberton et al., 1992). The occurrence of ripple laminations and lenticular bedding also suggest that there was frequent fluctuations in current strength, while reactivation surfaces also reflect that a stronger velocity current eroded the surface of pre-deposited sands followed by the deposition of another sand bed from subsequent current. Such indicators are common in subtidal and intertidal settings (Prothero and Schwab, 1996). 
Am. J. Sci. Ind. Res., 2011, 2(1): 37-48

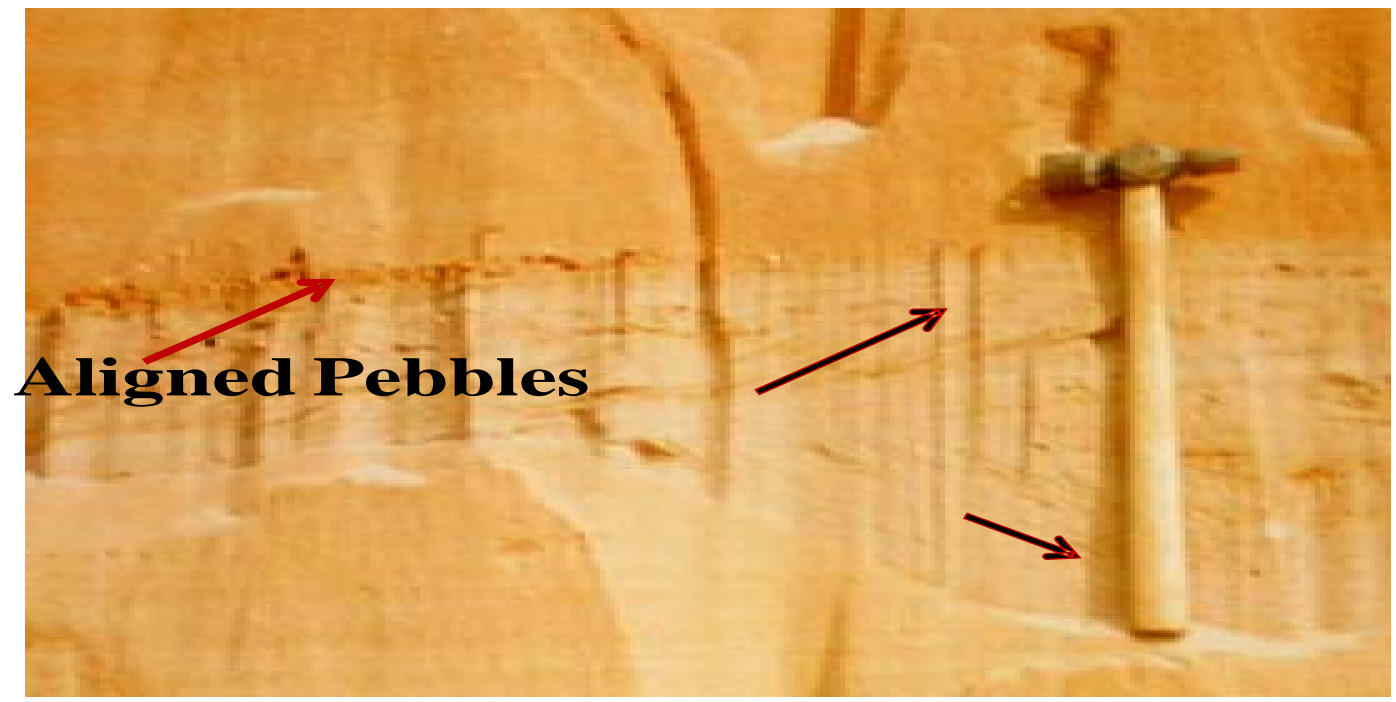

Plate 1: Aligned pebbles and unidirectional cross beds at Umunachi section

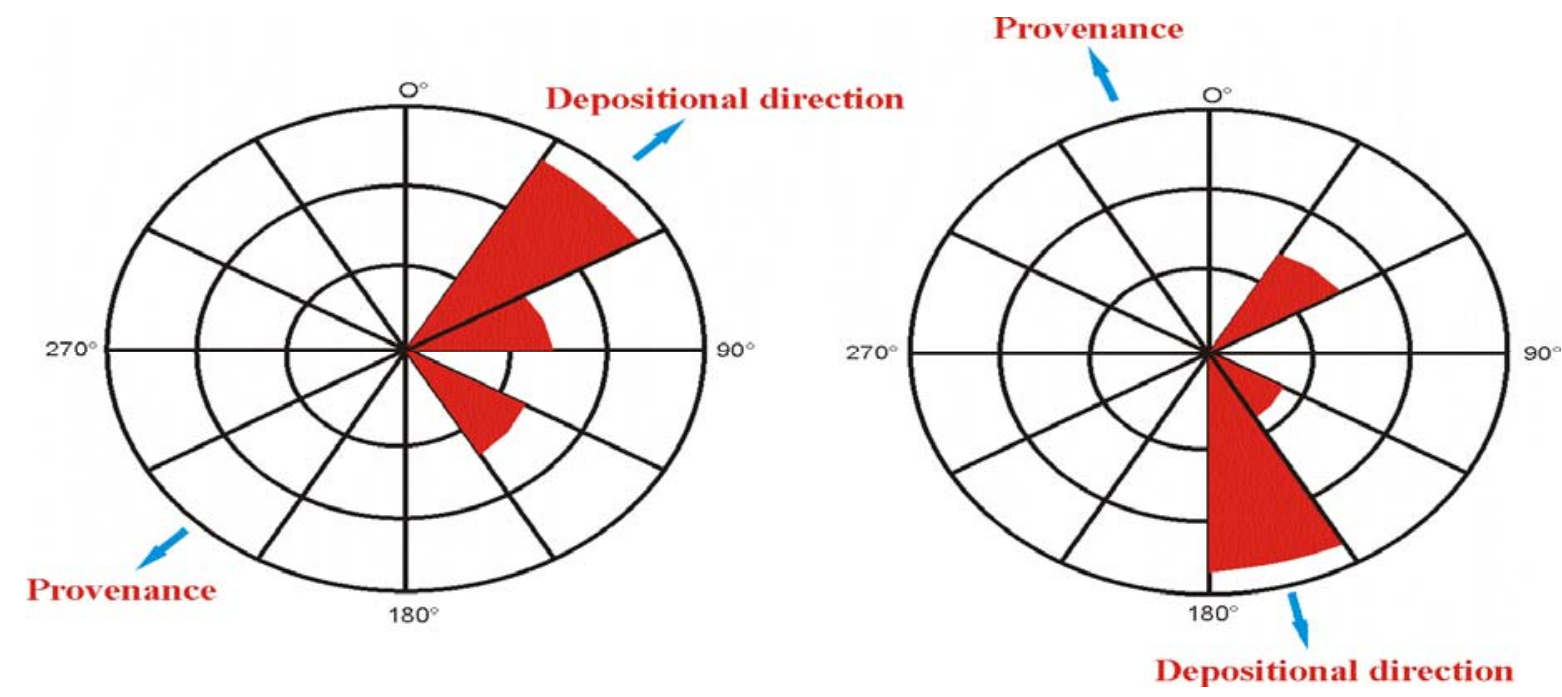

Fig 3: Rose diagrams obtained from paleocurrent data obtained from the conglomeritic and crossbedded facies (facies association I). 


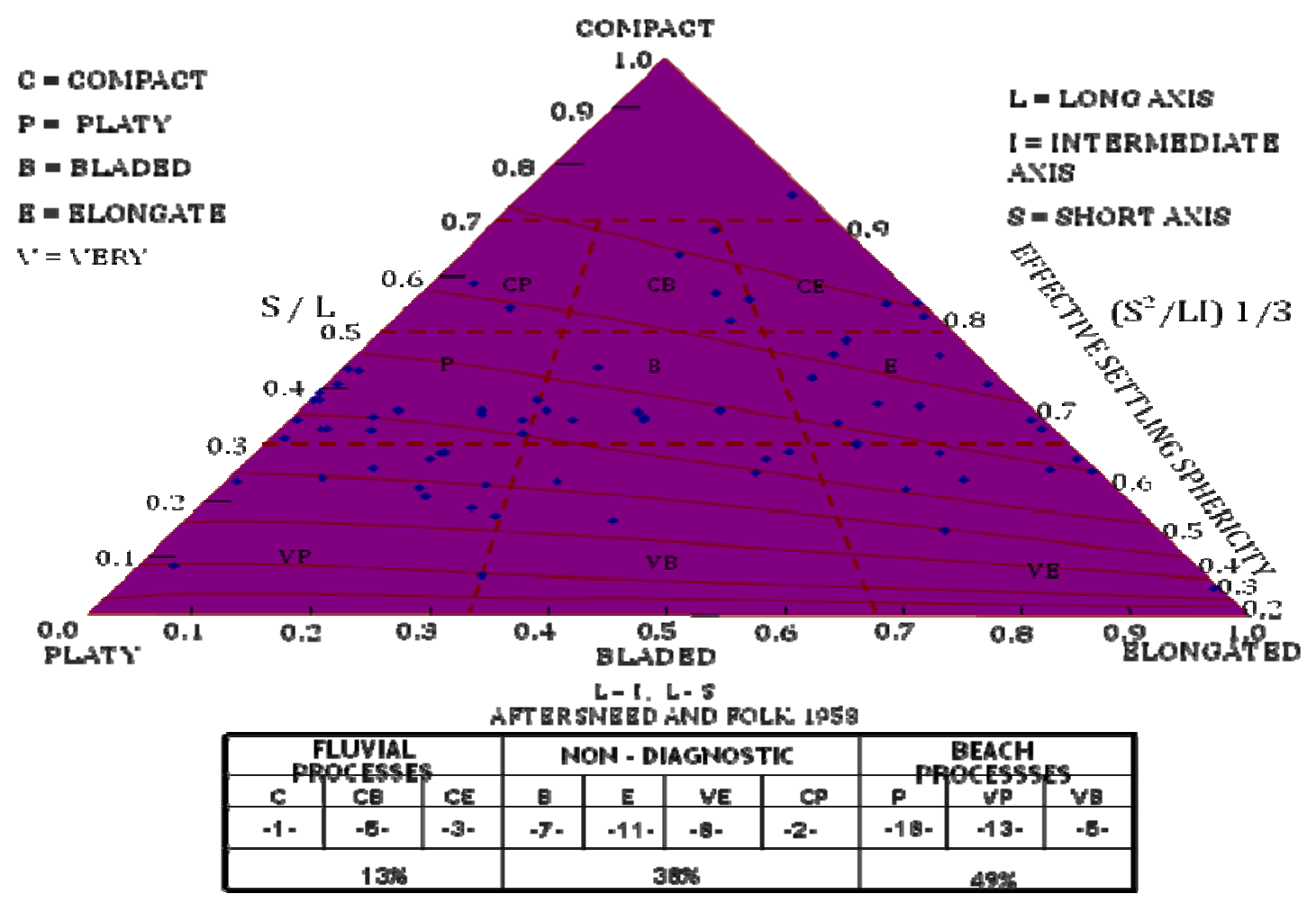

Fig 4: Triangular plot for pebble sampled from the conglomeritic facies.

Facies Association II: This estuarine facies is made up of two subfacies- heterolithic and laminated facies. The heteroliths are made up of sandstones with mud intercalation at intervals of $0.5 \mathrm{~m}$ thick. The sands are medium-fine grained and pebbly with a total thickness of $15 \mathrm{~m}$. There is also the presence of fine laminated siltstones with claystones and fine grained sandstones. The muddy intervals are strongly bioturbated and wavy laminated while the sandstone intervals which are sandwiched within the claystone are characterized by mudraped tangential crossbeds. The entire unit is characterized by abundant burrows belonging to the Skolithos ichnofacies. Furthermore, the inclined beds containing fine-grained sandstones, siltstones and thin mudrocks are interpreted as heterolithic strata, and represents lateral accretion deposits of point-bar in tidally-influenced rivers especially when associated with rhythmic and persistent mud drapes (Nilsen, 1982). The heteroliths (Ukpo Akpu, Ifite Ukpo and Umunya sections) also suggests deposition in a subaqueous environment under the influence of tidal currents. Such environments within the tidal zone include tidal channel and proximal estuarine settings. Intensely burrowed beds and the presence of skolithos ichnofacies reflect a well-oxygenated lower shoreface environment. The upward transition from proximal estuarine / lagoonal facies to coarsening-upward sand bodies characterized by wave-generated sedimentary structures indicates seaward progradation of shoreface parasequence (Scott, 1992; Walker and Plint, 1992). 
Am. J. Sci. Ind. Res., 2011, 2(1): 37-48

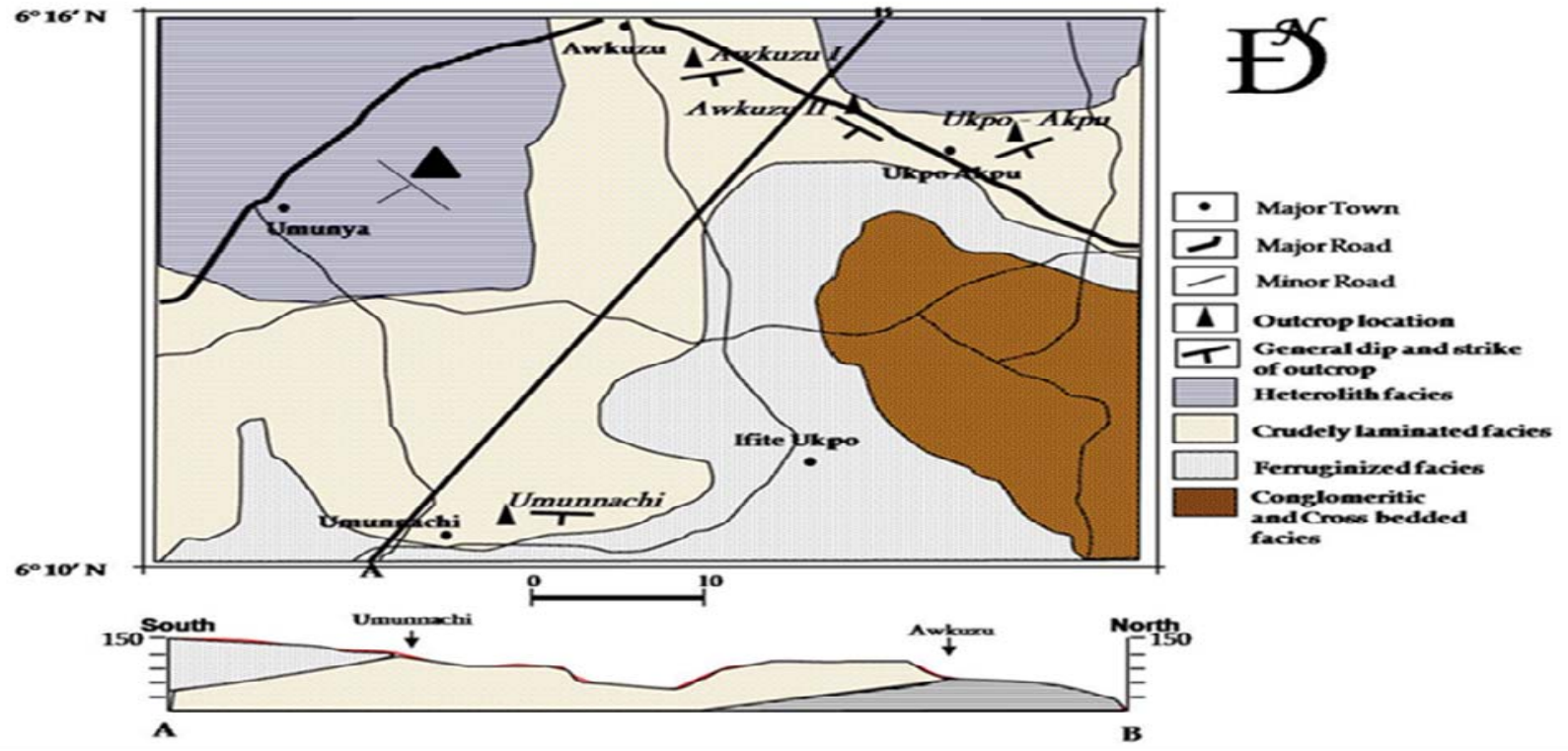

Fig 5: Facies map of the study area

$\mathbf{s w} \leftarrow$

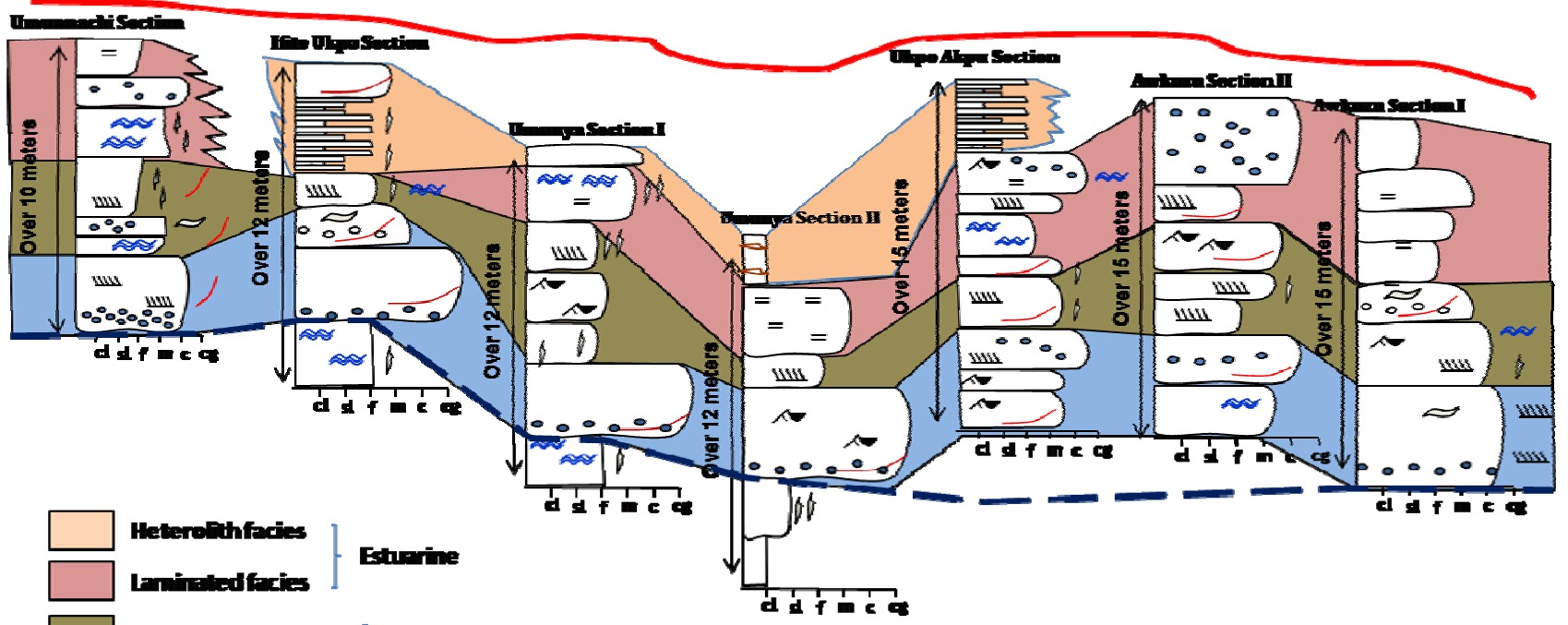

Croseboditalfacies

Condomeritic facies

Purial and Thtaly hifuenced Funil

IAchrad.

\begin{tabular}{|c|c|c|c|c|}
\hline 88 & ruble & $\infty$ & 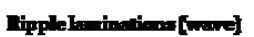 & Hill Manerambels \\
\hline- & Fla: bedres & $\beta$ & Fiotumbatim/burnom & - Mud/diphips \\
\hline e & Truafhoricheds & $=$ & Farlelta intisn & 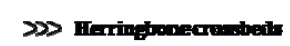 \\
\hline$\infty$ & Reantwailsnsurther & $\infty$ & Sandlenoe & Farroginizim \\
\hline
\end{tabular}

Fig 6: Correlation panel for the studied outcrops 
Am. J. Sci. Ind. Res., 2011, 2(1): 37-48

Table 1: Textural data and reservoir parameters of rocks in the study area obtained by use of empirical formula (after Krumbrien and Monk, 1942; Hsu, 1977).

\begin{tabular}{|l|l|l|l|l|}
\hline Sample No & Sample Facies & Median Size $\left(\mathbf{d}_{\mathbf{5 0}}\right)$ & Sorting, $\boldsymbol{\sigma}$ (phi unit) & Permeability (D) \\
\hline $\mathrm{AA} / 1$ & Fluvial & 0.22 & 0.28 & 121.3 \\
\hline $\mathrm{AA} / 2$ & Fluvial & 0.18 & 0.35 & 76.5 \\
\hline $\mathrm{AA} / 4$ & Fluvial & 0.19 & 0.70 & 85.4 \\
\hline $\mathrm{AA} / 6$ & Fluvial & 0.25 & 0.59 & 102.8 \\
\hline $\mathrm{AA} / 8$ & Fluvial & 0.17 & 0.32 & 74.7 \\
\hline $\mathrm{AA} / 12$ & Fluvial & 0.21 & 0.45 & 60.3 \\
\hline $\mathrm{AA} / 14$ & Fluvial & 0.30 & 0.39 & 129.6 \\
\hline $\mathrm{AA} / 17$ & Fluvial & 0.23 & 0.21 & 103.3 \\
\hline $\mathrm{AA} / 19$ & Fluvial & 0.20 & 0.47 & 93.6 \\
\hline $\mathrm{AB} / 7$ & Tidal & 0.16 & 0.80 & 38.6 \\
\hline $\mathrm{AB} / 8$ & Tidal & 0.15 & 0.75 & 31.1 \\
\hline $\mathrm{AB} / 10$ & Tidal & 0.13 & 0.61 & 39.5 \\
\hline $\mathrm{AB} / 13$ & Tidal & 0.20 & 0.75 & 27.3 \\
\hline $\mathrm{AB} / 14$ & Tidal & 0.17 & 0.61 & 45.0 \\
\hline $\mathrm{AB} / 17$ & Tidal & 0.15 & 0.52 & 37.9 \\
\hline $\mathrm{AB} / 19$ & Tidal & 0.21 & 0.48 & 34.5 \\
\hline $\mathrm{AC} / 1$ & Estuarine & 0.16 & 0.52 & 30.4 \\
\hline $\mathrm{AC} / 3$ & Estuarine & 0.21 & 0.55 & 23.4 \\
\hline $\mathrm{AC} / 5$ & Estuarine & 0.20 & 1.11 & 17.0 \\
\hline $\mathrm{AC} / 8$ & Estuarine & 0.13 & 0.93 & 16.7 \\
\hline $\mathrm{AC} / 11$ & Estuarine & 0.22 & 0.76 & 18.2 \\
\hline $\mathrm{AC} / 13$ & Estuarine & 0.14 & 0.65 & 34.4 \\
\hline $\mathrm{AC} / 14$ & Estuarine & 0.12 & 1.23 & 21.6 \\
\hline $\mathrm{AC} / 15$ & Estuarine & 0.20 & 0.95 & 30.3 \\
\hline $\mathrm{AC} / 20$ & Estuarine & 0.11 & 0.59 & 21.2 \\
\hline & & & & \\
\hline
\end{tabular}

Variation of Permeability with Depositional Environment

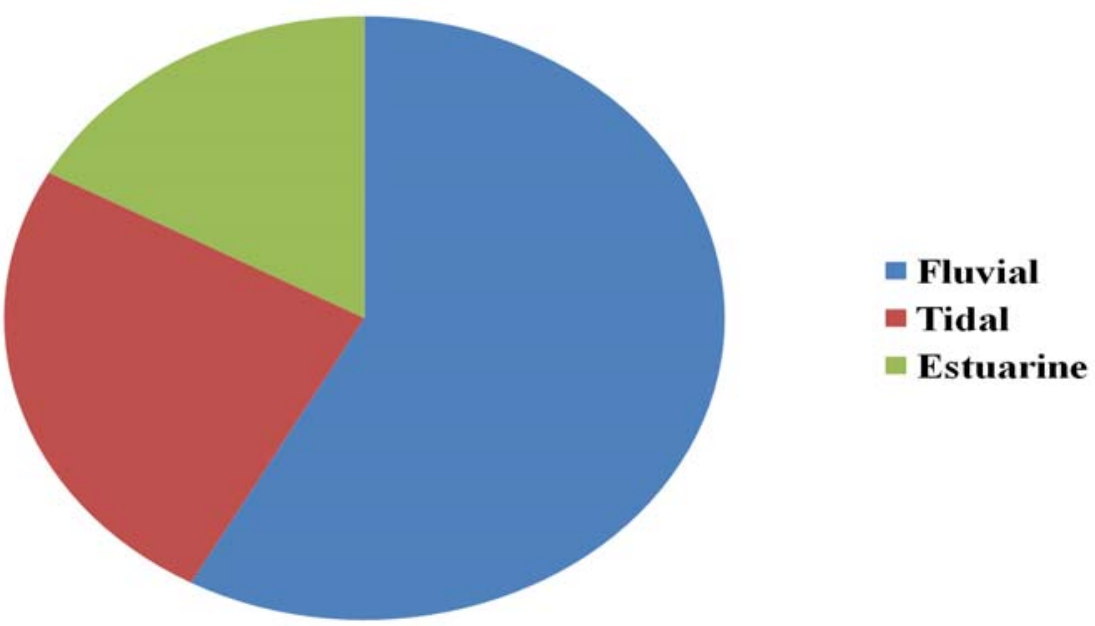

Figure. 7: Variation of permeability with depositional environment 
Am. J. Sci. Ind. Res., 2011, 2(1): 37-48

Table 2: Summary of clay minerology

\begin{tabular}{|c|c|c|c|c|}
\hline Clay mineral & Type of silicate & Formulae & Ionic elements & Clay mixture \\
\hline Wickenburgite & Phyllosilicate & $\mathrm{Pb}_{3} \mathrm{CaAl}_{2} \mathrm{Si}_{10} \mathrm{O}_{27} .3 \mathrm{H}_{2} \mathrm{O}$ & $\mathrm{Al}^{3+}, \mathrm{Ca}^{2+}$ & Kaolinite \\
\hline Ferrisurite & Phyllosilicate & $\begin{array}{l}(\mathrm{Pb} ; \mathrm{Ca})_{2.5}\left(\mathrm{CO}_{3}\right) 1: 75(\mathrm{OH} ; \mathrm{F}) 0: 75 \\
\left(\mathrm{Fe}^{3+} ; \mathrm{Al}_{2} \mathrm{Si}_{4} \mathrm{O}_{10}(\mathrm{OH})_{2} \mathrm{nH}_{2} \mathrm{O}\right.\end{array}$ & $\begin{array}{l}\mathrm{Al}^{3+}, \mathrm{Fe}^{3+} \\
\mathrm{Pb}^{2+}, \mathrm{Ca}^{2+}\end{array}$ & $\begin{array}{l}\text { Kaolinite- } \\
\text { chlorite }\end{array}$ \\
\hline Surite & Phyllosilicate & $\begin{array}{l}(\mathrm{Pb} ; \mathrm{Ca})_{2.3}(\mathrm{CO} 3) 1: 5(\mathrm{OH} ; \mathrm{F}) 0: 5 \\
\left(\mathrm{Al} ; \mathrm{Fe}^{3+}\right)_{2}(\mathrm{Si} ; \mathrm{Al})_{4} \mathrm{O}_{10}(\mathrm{OH})_{2 n} \mathrm{H}_{2} \mathrm{O}\end{array}$ & $\begin{array}{l}\mathrm{Al}^{3+}{ }^{3+} \mathrm{Pb}^{2+}, \mathrm{Ca}^{2+} \\
\mathrm{Fe}^{++}\end{array}$ & $\begin{array}{l}\text { Kaolinite- } \\
\text { chlorite }\end{array}$ \\
\hline Latiumite & Phyllosilicate & $(\mathrm{Ca}, \mathrm{K})_{4}(\mathrm{Si}, \mathrm{Al})_{5}\left(\mathrm{SO}_{4}, \mathrm{CO}_{3}\right)$ & $\mathrm{Al}^{3+}, \mathrm{Ca}^{2+}, \mathrm{K}^{+}$ & Kaolinite-illite \\
\hline Lawsonite & Sorosilicate & $\mathrm{CaAl}_{2} \mathrm{Si}_{2} \mathrm{O}_{7}(\mathrm{OH})_{2} \mathrm{H}_{2} \mathrm{O}$ & $\mathrm{Al}^{3+}, \mathrm{Ca}^{2+}$ & Ilvaite \\
\hline Mordenite & Tectosilicate & $(\mathrm{Ca} ; \mathrm{Na} ; \mathrm{K}) \mathrm{Al}_{2} \mathrm{Si}_{10} \mathrm{O}_{24 .} .7 \mathrm{H}_{2} \mathrm{O}$ & $\mathrm{Na}^{+}, \mathrm{K}^{+}, \mathrm{Ca}^{2+}$ & Zeolite \\
\hline $\begin{array}{l}\text { Meionite } \\
\text { sodian }\end{array}$ & Tectosilicate & $(\mathrm{Ca}, \mathrm{Na})_{2}(\mathrm{Si}, \mathrm{Al})_{6} \mathrm{O}_{12}\left(\mathrm{CO}_{3}\right) 0.5$ & $\mathrm{Ca} 2+, \mathrm{Na}+, \mathrm{Al} 3+$ & $\begin{array}{l}\text { Scapolite } \\
\text { (feldspathoid) }\end{array}$ \\
\hline
\end{tabular}

\section{DISCUSSION}

The channel sedimentary package in the studied succession depicts a mixed-load fluvial system (Galloway, 1975). This matches with the Donjek-type model proposed by Miall (1977) where there are stacks of fining-upwards channel sands (fig.6). This fluvial-dominated upper deltaic plain system with mixed sediment load (conglomerates and sands) are usually found in braided channels characterized by relatively high slopes, large sediment discharge and a variable flow pattern as found in the Mississippi delta. The generally multistoried sandstones in the studied succession with an extensive sheet deposit show good reservoir prospects.

Empirical permeability correlation of the reservoir sandstones in the study area shows that the conglomeratic fluvial channel facies as better reservoir intervals with lower values in the closely stacked laminated tidal and estuarine sand facies of the Ukpo Akpu and Umunachi sections. This is evident from their high porosity (inferred from low clay content and coarse sands), thick beds and extensive sheet geometry although locally compartmentalized by thin ironstone layers. This hierarchical variation also corresponds with differences in their grain sizes, degree of sorting, compaction, bioturbations, wave ripple laminations and mud drapes and other diagenetic influences. It also shows that sedimentological controls and depositional facies is a fundamental control on reservoir quality. Based on petrographical studies, the reservoir heterogeneity at the microscale is mainly controlled by compaction; fracturing of the grains; chemical dissolution of unstable minerals; pressure solutions; and cementation. Compaction leads to recrystallisation and precipitation of pressure solutions between these grains- thus reducing the intergranular pores volumes and not good for pore connectivity. Pressure solutions of quartz act as cements, a major control on reservoir quality (Ollson et.al. 2002; Hubert et.al. 2008). At the megascale (within sections, beds and laminas), major controls are clay drapes on foreset planes of cross-beds, clay dispersal within the sands, bioturbations, ferruginized bands of sands and coarse grained lags at the base of channel. The reworking activities of the organisms close up the original (primary) pores and matrix leading to secondary alterations. The ferruginized bands affect vertical permeability with little effect on horizontal permeability although verrtical permeability is fairly enhanced by vertical structures of Ophiomorpha shafts in the upper part of the tidally influenced conglomeratic facies. This also enhances good reservoir interconnectivity. The laterally extensive cross-bedded, tidally-influenced fluvial channel sands also show good reservoir intervals with good lateral extent (sheet geometry), continuity and thickness. However, the presence of clay and mud drapes on the foreset planes of the cross-beds is likely to affect permeability (thereby impeding the flow of fluid). Different facies have their peculiar effects on reservoir properties; coarse- grains of 
channel base may result in increased permeability, the cross-bedded boundaries and grain size variations results in permeability contrast at a lamina scale, while ripple laminated siltstones function as impermeable barriers to fluid flow between discrete intervals (Reynolds et. al.,1998; Ye and Kerr, 1999). According to Magoon and Dow (1994), primary porosity is best preserved in channel sandstones because they have not been subjected to severe changes that may occur due to continuous transportation, re-deposition and other diagenetic and

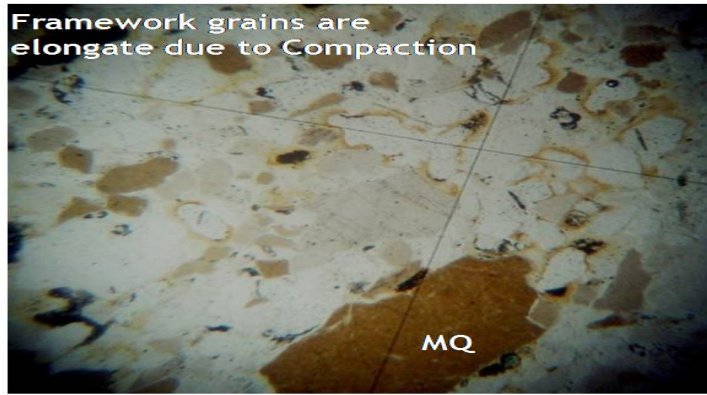

Matrix materials are major inhibitors to RESERVOIR PORE CONNECTIVITY

Pressure solutions of Quartz act as cements...... a major reduction to RESERVOIR QUALITY. tectonic effects. Also, the reservoir quality of braided channels is good because they are mineralogically and texturally mature relative to that of other environments. The narrow, lens-like sand bodies of the massive facies lack lateral continuity and homogeneity as it terminates before the Umunachi section. Also, the alternating crudely laminated facies are separated by the thin heterolithic interval (Ukpo Akpu section) giving rise to discontinuity in the reservoir bodies.
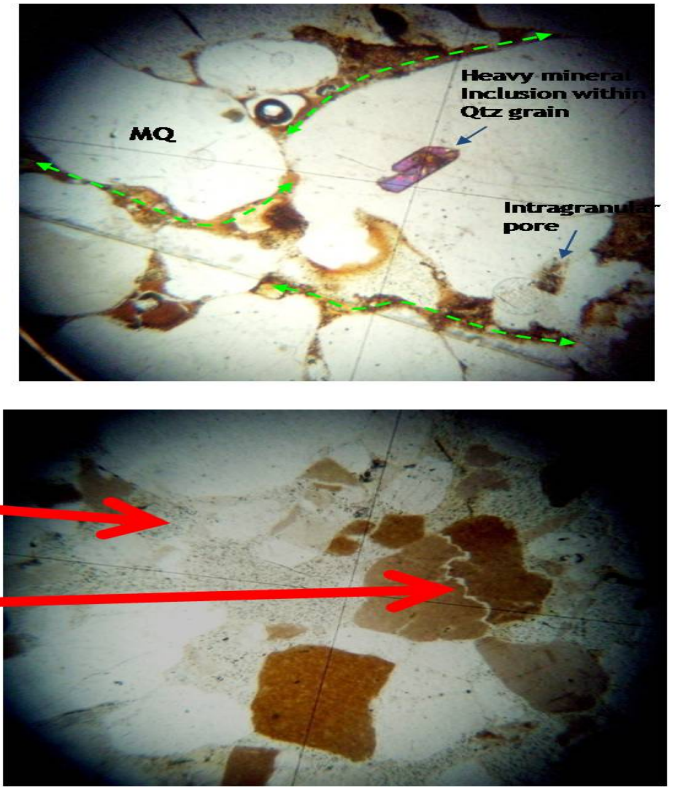

Plate 2: Thin section photographs of some of the thin sections

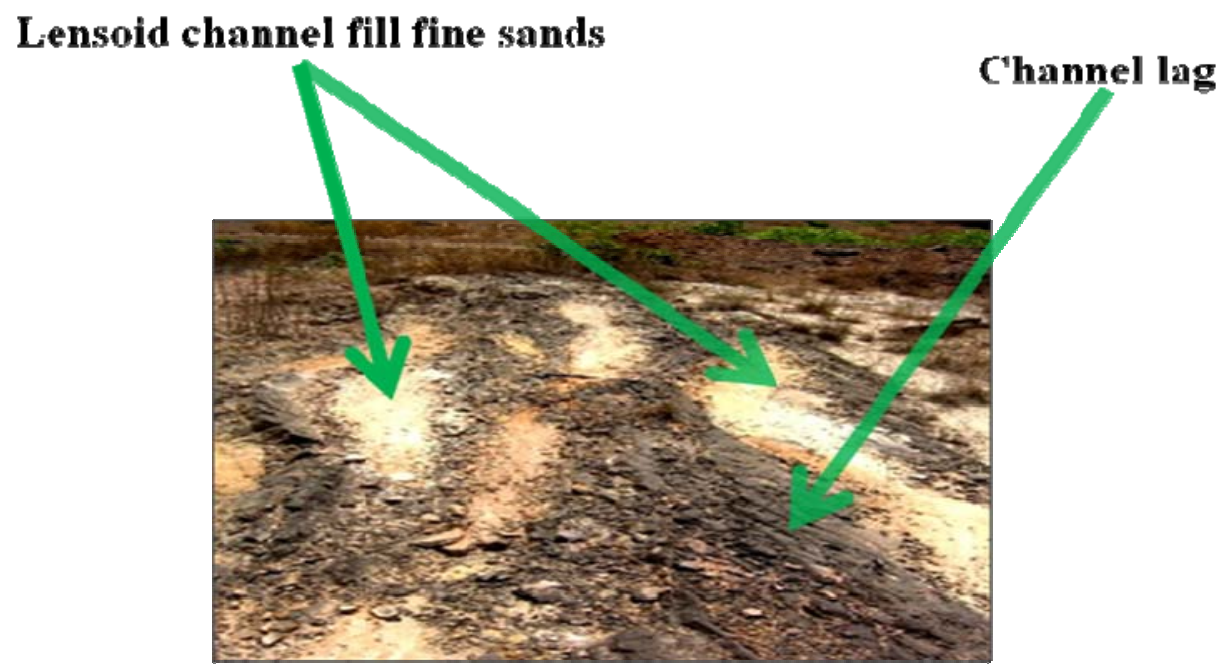

Plate 3: channelized sand exposure at the Ifite section. 
Most minerals contained are diagenetic products of the weathering of aluminosilicates. The clay facies contains kaolinite-smectite, kaolinite-chloritesmectite, and kaolinite-illite-chlorite, based on the base cations confirmed (Table 2). Some of these silicates for example Ferrisurite, Surite, Latiumite and Grossular hydroxylian, show evidence that the sediments are detrital deposits derived from aluminium-rich rocks or impure feldspathic limestones. Other secondary silicates recorded like mordenite minerals are hydrous aluminosilicates formed from the weathering of hydrothermal vein deposits or the alteration of feldspathoid-like rocks (Hibbard, 2002). The clay is predominantly detrital in origin with the mixed nature being inferred from the presence of laminated and non-laminated clay minerals. Allogenic clays are characteristically in the form of thin intercalated laminae, clay rip-up clasts, biogenic pellets, and biogenically introduced burrow fillings and linings (Wilson and Pittman, 1977). Authigenic clays, which occur as pore linings, pore fillings, pseudomorphous replacements, and fracture fillings, are the major controls on reservoir quality because permeability and water saturation are particularly sensitive to the relative abundance of these clays.

Implication for deepwater reservoirs : The shoreface sands as observed in parts of the study area are the source materials for turbidity currents waiting to be triggered, transported across the shelf and deposited at the foot of slope or on the abyssal plain to form the deepwater reservoirs. Turbidites commonly show predictable changes in bedding from coarse grains at the bottom to finer lamination at the top (Bouma sequence), due to differential settling velocities of the particle size present. These shoreface sands form the ancient analogues and therefore serve as a proxy for deepwater reservoir studies. Submarine fans and turbidites, composed of accumulation of sand, are some of the world's prolific sand-rich reservoirs. The enormous cost of finding and producing hydrocarbon reserves make deepwater reservoir-development strategies much different from those of onshore and shallow marine fields. Ideally, time to find oil must be minimized for project viability, fewer wells tend to be drilled for reservoir evaluation, and increasing use of subsea installation means of well intervention is extremely costly and difficult. As a result, geologists must understand and model these reservoirs with significantly less well-log data, borehole images and cores. This scarcity of field-specific information has led to the increased study of submarine fan (reservoirs) and turbidite analogues to help geologists build predictive models for the complex distribution and architecture of these reservoirs. This approach to reservoir studies reduces the development cost and risk associated deepwater reservoirs. It also increases confidence in exploration and subsequent decision making. Therefore, given the difficulty of studying recent modern deepwater sedimentary systems, researchers now study ancient outcrop analogues to unravel more information on the heterogeneities associated with deepwater hydrocarbon reservoir targets.

\section{CONCLUSION}

Two major levels of sedimentary controls were observed in the study area. Reservoir heterogeneity at the microscale (within the grains and minerals) are mainly controlled by compaction, fracturing of the grains, chemical dissolution of unstable minerals, pressure solutions, and cementation, while at the megascale (within the sections and beds), major controls are bioturbations, clay drapes on foreset planes of cross-beds (tidal influence), clay dispersal within the sands, ferruginized bands of sand and coarse grained lags at the base of channel. Shoreface sands as observed in parts of the study area are the feeders for turbidity currents; waiting to be triggered, transported beyond the shelf and deposited at the foot of slope or on the abyssal plain to form the deepwater reservoirs. These shoreface sands also serve as ancient analogues for the deep water sedimentary systems.

\section{REFERENCES}

Archer, A.W. and Kvale, E.P., 1989. Seasonal and yearly cycles within tidally laminated sediments; an example from the Pennsylvanian in Kentucky, Indiana, and Illinois. Indiana Geological Survey, Illinois Basin Consortium, no. 1, 45-46.

Avbovbo, A. A. 1978. Tertiary Lithostratigraphy of the Niger Delta. AAPG Bulletin, vol. 62, $295-306$.

Benkhelil, J.,1989. The origin and evolution of the Cretaceous Benue Trough of Nigeria: Journal of Africa Earth Sciences, vol.8, 251-282.

Collinson, J.D, and Thompson, D.B., 1989. Sedimentary Structures: Chapman and Hall, London, 207p.

Dobkin, J.E. and Folk, R.L., 1970. Shape Development on Tahiti: Journal of Sedimentary Petrology, vol. 40, 1167-1203.

Galloway, W. E., 1975. Process framework for describing the morphologic and stratigraphic evolution of deltaic 
depositional systems: In: Broussard, M. L., (ed.), Deltas: Houston Geological Society, 87-98.

Adegoke, O.S., 1969. Eocene Stratigraphy of Southern Nigeria: Colloque sur I' Eocene, III. Bureau de Recherché Geologiques et Minieres, vol. 69, 20 - 48.

Hsu, K.J., 1977. Studies of Ventura Field, California, II. Lithology, Compaction, and Permeability of sands: AAPG Bulletin, vol.61, 169 - 191.

Hettinger, R. D., 1995. Sedimentological Descriptions and Depositional Interpretation in Sequence Stratigraphic context, of two 300-meter Cores from Upper Cretaceous Straight Cliffs Formation Kaiparowits Plateau, Kane County, Utah: US Geological Survey Bulletin 2115-A, 29-33.

Kreisa, R.D., G.I. Unomah, S.D. Joiner, Y.R. Oluwale, and Leininger, S.C., 1999. Improved reservoir description and development through quantitative integration of core data: Nig. Assoc. Petrol. Expl. Bull., vol.14, 1-17.

Krumbrien, W.C. and Monk, G.D., 1942. Permeability as a function of size parameters of unconsolidated sand: Pet. Technol, vol.5, $1-11$.

Leckie, D.A. and Singh, C., 1991. Estuarine deposits of the Albian Paddy Member (Peace River Formation) and Lowermost Shaftsbury Formation, Alberta, Canada: Journal of Sedimentary Petrology, vol. 61, 820-845.

Magoon, L.B., and Dow, W.G., 1994. The Petroleum System - From Source to Trap: AAPG Memoir, vol.60, $655 p$.

Martin, R.G., 2006. Width and thickness of Fluvial Channel Bodies and Valley fills in the Geological Record: A literature compilation and classification: Jour. Sedm. Research, vol. 76, $731-770$.

Miall, A.D. 1977. A review of the braided - river depositional environment: Earth Science Reviews, vol.13, 5-6.

Nilsen, T.H. (ed.), 1982. Fluvial sedimentation and related tectonic framework, Western North America: Geology, vol. 36, 523-524.

Nwajide, C. S., 1979. A lithostratigraphic analysis of the Nanka Sands, South-eastern Nigeria: Journal of Mining and Geology, vol. 16, 100-110.

Oboh-lkuenobe, F. E., Obi, G. C. and Jaramillo, C. A., 2005. Lithofacies, palynofacies and sequence stratigraphy of Palaeogene strata in southeastern Nigeria: Journal of African Sciences, vol. 41, 75-100.

Obi, G.C., Okogbue, C.O. and Nwajide, C.S., 2001. Evolution of the Enugu Cuesta: A tectonically driven erosional process: Global Journal of Pure \& Applied Sciences, vol. 7, 321-330.

Pemberton, S. G., Mac Eachern, J. A. and Frey, R. W., 1992. Trace fossil Facies models: environmental and allostratigraphic significance: In: Walker R.G. and James, N.P. (eds.), Facies Models, Geol. Assoc. Canada, 47-72.

Prothero, D.R. and Schwab, F., 1996. Sedimentary Geology, New York, W.H. Freeman and Company, 575-578.

Reyment, R.A., 1965. Aspects of the Geology of Nigeria: University of Ibadan Press, Nigeria, 145p.

Shanley, K.W., McCabe, P.J., and Hettinger, R.D., 1992. Tidal influence in Cretaceous fluvial strata from Utah, U.S.A. - A key to sequence stratigraphic interpretation: Sedimentology, vol.39, 900-935.

Short, K. C., and Stauble, A. J., 1967. Outline of geology of Niger Delta: AAPG Bulletin, vol. 54, 750-780.

Simpson, A., 1954. The Nigerian Coalfield: The Geology of parts of Owerri and Benue Provinces: Bull. Geological Survey of Nigeria, no.24, $85 \mathrm{p}$.

Steinmetz, R., 1962. Analysis of vectorial data: Jour. of Sed. Pet., vol. 32, 801-812.

Walker, R.G. and Plint, A.G., 1992. Wave- and stormdominated shallow marine systems: In: Facies Models: Response to Sea Level Change: R.G. Walker \& N.P. James (eds.), Geological Association of Canada. St. Johns, Newfoundland, 219-238.

Wilson, M.D., and Pittman, E.D., 1977. Authigenic clays in Sandstones: Recognition and Influence on Reservoir Properties and Paleoenvironmental analysis: Jour. of Sed. Pet., vol.47, 3- 31.

Ye, L. and Kerr, K.Y., 1999. Facies Architecture of the Bluejacket Sandstone in the Eufaula Lake Area, Oklahoma: Implication for Reservoir characterization of the Subsurface Bartlesville sandstones: In: R. Schatzinger and J. Jordan (eds.), Reservoir characterization - Recent Advances, AAPG Memoir, vol. $71,29-44$. 